\title{
Perception Graduates Science Education in Socio Scientific Issues Related with Scientific Communication and Critical Attitude
}

\author{
Hanis Pramudawardani ${ }^{1, *}$ Zuhdan Kun Prasetyo ${ }^{1}$ \\ ${ }^{I}$ Master of Natural Science Education, Faculty of Mathematics and Natural Sciences, Universitas Negeri \\ Yogyakarta, Indonesia \\ ${ }^{2}$ Department of Natural Science Education, Faculty of Mathematics and Natural Sciences, Universitas Negeri \\ Yogyakarta, Indonesia \\ *Corresponding author. Email: hanispramudawadani.2019@student.uny.ac.id
}

\begin{abstract}
This study aims to investigate the views of science education graduates about Socio Scientific Issues (SSI) and SSI's relationship with scientific communication and critical attitudes. The research data were collected using a questionnaire that included five open-ended questions. The research data were collected in August-October in the 2020-2021 academic year. This research is qualitative research. The results of the study, it was found that the graduates of science education have different views, but some samples have relatively the same view. The science education graduate is of the view that SSI can be used to improve critical attitude and scientific communication. During the Covid-19 pandemic, science learning could put Covid 19 into the SSI' context.
\end{abstract}

Keywords: Socio scientific issues, Bachelor of science education, Critical attitude and scientific communication, Covid-19.

\section{INTRODUCTION}

Individuals who have scientific literacy skills must afford to face, negotiate, and create decisions in an everyday situation involving science. Science plays a very important role in the modern life of society and scientific ideas. Science education is a subject that supports the ability of students to engage in scientific practice. The role of education must maximize the involvement of students in practice, however education is currently faced with serious problems because the world, including Indonesia, is faced with a serious problem, namely Covid 19 . This problem has an impact on learning activities that occur. The government limits face-to-face activities in class during the Covid 19 period. The impact of this limitation makes teachers have to think about what strategies can be used to produce students according to the goals in the 2013 Curriculum education.

Science Education is understanding of the nature of educational science, relating to the accession of purpose to emphasize intellectual and communication skills development; and offer a positive character and attitude; for goals in social emphasize decision making and cooperative learning about social science problems [1]. The 2013 curriculum requires all subjects including science to contribute to the formation of attitudes and skills [2]. Science education requires the role of educators to teach science content by helping students to be more involved in negotiations and decision-making correlated with social problems related to science content.

Use of content with Socio Scientific Issues (SSI) can be useful to support learners about how to use content when facing global problems connected substantially to science [3]. The degree and manner in which individuals use content knowledge depend on the context used [4]. Sadler's research contains perspective importance of SSI as a context in education [4]. The learning context requires students to face several problems and to gain complex experiences. SSI provides context for reasons for problems in a relevant way [5].

SSI is a representation of science that is significant with social problems [1] [7] which provides a learning 
experience by increasing the active participation of learners in social practices outside the classroom [4]. The SSI problem is a problem that is controversial and related to science, but without a clear solution [8], but some solutions are plausible. The solutions notified by scientific principles, data, and theory, but cannot be completely based on scientific considerations. Problems and potential actions related to these problems be affected by various social factors, such as ethical, economic, and political.

Anagün \& Özden's research objective is to investigate the views of prospective Science teachers and classroom teachers about SSI and competencies in using SSI in science and technology teaching [6]. Research by Chung et al. showed that SSI instruction has a considerable ability of students to grasp other people's key brainchild and to appreciate the views of others, thereby positively influencing the development of active statements, and to improve communication skills needed to improve literacy scholarly in the $21 \mathrm{st}$ Century [9].

The development of critical thinking using SSI requires the role of the teacher [10]. Effect of science teaching activities through discussion and decisionmaking processes on the critical attitudes of teacher candidates that contribute to the development of scientific thinking [11]. Based on the relevant research above, it appears that teachers lead a significant role in the development of SSI. The goals of this research were used to determine the views of undergraduate science education graduates about SSI problems, the relationship between SSI and critical attitudes and communication skills, and the use of SSI during the Covid-19 period.

\section{RESEARCH METHOD}

This research type utilizes descriptive research. The analysis technique in this research is descriptive qualitative and a sample selected using a purposive sampling method. The sample criteria used, adopted from Anagün \& Özden's research, include 1) Graduates of Science education, 2) Samples participated voluntarily. The number of samples used was 28 people, with $10.71 \%$ male and $89.29 \%$ female.

Data collection was carried out in August-October 2020 using internet media, namely, google form with a questionnaire containing 5 open questions so that researchers get an overall picture because it enables participants to express their true beliefs or opinions. The questions used were related to SSI, critical attitudes, scientific communication, and the use of SSI during the Covid-19 period which were carried out for science education graduates.

\section{RESULT}

\subsection{The views of science education graduates on Socio Scientific Issues}

Science graduates define SSI problems in various opinions, one of which defines SSI as a controversial issue and is related to other aspects such as the following opinions like "social problems or problems that are trending or controversial that can be seen from a scientific perspective" (S1), "Dilemma, controversial, debated scientific problems in society, and require solutions from various aspects". (S4), SSI is a social problem that intersects with social "(S26). Another opinion argues that SSI is the relationship between science and social phenomena in society" an approach that connects science and phenomena in the form of social issues in society" (S2).

Another definition holds that SSI is a problem that comes from real life, such as the following opinion: "SSI is a lesson that connects a real problem with natural science" (S3). Another view that SSI is a context is as follows: "SSI is a context that can be integrated into science learning." (S13). From a sample of undergraduate science education graduates, it is confirmed that SSI is a controversial issue related to social science issues. There is one sample of undergraduate science education graduates who did not give an opinion on SSI.

\subsection{The views of science education graduates on the benefits of using Scientific Social Problems in Science learning and for students}

Science graduates have the view that SSI applied to science learning has various benefits, namely to improve scientific literacy, critical thinking skills, decision making, argumentation skills, study phenomena that exist in everyday life so that it can increase student curiosity and student interest. The views of science graduates are as follows: "improve scientific literacy, thinking skills, decision-making skills, argumentation skills" (S4), "helping students direct students to study the phenomena that occur around them. students, then apply it to science learning. "(S2)," The use of SSI in learning will attract students' interest and enthusiasm for learning. SSI is an issue that is usually hotly discussed by the community and is controversial. This issue can be very closely related to everyday life in their respective environments. using social problems will certainly 
stimulate students' curiosity in solving a problem and finding the correct answer to the problem." (S8).

Other science graduates think that SSI is useful as: "SSI provides hot issues to give student understanding towards the science material being studied." (S11), "SSI makes science learning connected to students' real lives, as a forum for learning outcomes, such as NOS, increasing dialogical arguments, the ability to evaluate scientific data and information, and as a component of scientific literacy." (S27). "SSI uses to help students in the skill of critical thinking" (S6), "SSI is needed to understand and learn about issues around it so that there is no misconception or understanding about what is happening"(S9), "developing life skills" (S15), "SSI can be a link between real issues/problems that occur in society and learning (IPA) and this causes a sense of interest from students because of the problems that occur around them so that students will have a desire to explore the knowledge that is happening around them." (17).

Some science education graduates have the view that SSI is good to be applied in science learning, but they do not give an idea why SSI is good to be applied. From these positive views, there is a view that illustrates that SSI requires in-depth knowledge with the following views "The application of SSI requires a sufficiently deep knowledge because it must be able to relate a problem to the aspect of natural science" (S3) and there is one sample who does not know what is the role of SSI.

\subsection{View of science education graduates on the influence of SSI on increasing the critical attitude of students}

This science education graduate believes that SSI has an important role for students in increasing critical attitudes. The views of science graduates who have the view that SSI plays a role in critical attitudes are as follows: "SSI is very closely related to trending issues in society, which will encourage students 'curiosity in seeking information so that later it will shape students' critical attitudes. Science will make students critical of something that makes them seek information from various aspects related to science. "(S3). This view (S3) illustrates that the role of SSI in increasing students' curiosity will lead to thoughts in students which will lead to critical attitudes of these students." Socio-scientific problems can train students to think critically to link science with science. social problems in the surrounding environment, namely by carrying out activities such as identifying scientific problems in society, analyzing the impact of these problems on life and the environment, identifying and evaluating the consequences of problems or problems for the social life of the community and the surrounding environment, offering appropriate solutions. In overcoming these problems, creating or designing activity steps in finding the best solution. With this SSI strategy, students can produce scientific works that are beneficial to life." (S7). Students' thinking about the right solution in dealing with existing SSI problems will lead to the critical attitudes of students. Another view is "SSI helps students to analyze and evaluate problems, phenomena, and problems that must be solved by students." (S9). There are samples that do not know whether there is a relationship between critical attitude and SSI, but some are not sure.

\subsection{The view of science education graduates on the influence of SSI on improving students' communication skills}

Some science education graduates have the view that SSI has a positive effect on improving scientific communication such as the following view (S11) "SSI will improve critical thinking patterns so that their achievement is related to communication skills.", "Students speak based on facts, data, and knowledge in science so that it is not assumptions or presumptions. (S1). This view illustrates that critical thinking affects students' scientific communication skills. Some undergraduate science education graduates do not know whether SSI can improve scientific communication, but science education graduates have the view that SSI is related to scientific communication, namely "The process of arguing will hone scientific communication skills". (S4), "Students are able to discuss socio-scientific problems, argue, and communicate the results". (S13).

\subsection{The views of science education graduates regarding the utilize of SSI in science learning amid the Covid-19 pandemic}

Science education graduates have the view that SSI can be applied in science learning in the conditions of the Covid-19 pandemic and there is also an opinion that covid-19 can be used as a context for SSI, but there are 2 samples (S11 and S16) argued that SSI can be used in the midst of a pandemic without stating the reasons why SSI can be applied. Table 1 is about data on SSI's relevance to covid-19. 
Table 1. Relevance of SSI with Covid 19

\begin{tabular}{|c|c|}
\hline Responden & Questionnaire's Data \\
\hline$S 4$ & Covid-19 has the potential to be packaged into SSI \\
\hline S1 & $\begin{array}{l}\text { SSI-based learning can be applied by raising issues that are trending in society than } \\
\text { making these issues a foothold in learning about science content. For example, the } \\
\text { relationship between Covid-19 and the human respiratory system }\end{array}$ \\
\hline S2 & Students can learn about phenomena that are happening now about covid-19 \\
\hline$S 5$ & Need the provision of social problems during online learning due to covid-19 \\
\hline 56 & $\begin{array}{l}\text { Learning during covid-19 can be carried out to carry out scientific investigations about } \\
\text { natural phenomena that occur with the help of the internet }\end{array}$ \\
\hline S7 & $\begin{array}{l}\text { In a pandemic, students can further explore their thinking skills in analyzing social issues } \\
\text { related to the Covid-19 pandemic that can harm the environment and society, and } \\
\text { students can relate the issue of this pandemic to science that students have acquired. } \\
\text { For example, by studying what the coronavirus is, how the virus develops, how to prevent } \\
\text { it, and provide the right solution in handling it }\end{array}$ \\
\hline S8 & $\begin{array}{l}\text { The Covid-19 pandemic is definitely the biggest social issue this year. Everyone from the } \\
\text { top to the bottom knows about this pandemic. So, SSI's learning about covid-19 will } \\
\text { certainly be very much needed. In addition to providing a scientific view of the existence } \\
\text { of a pandemic, this is also necessary so that students can behave scientifically in the face } \\
\text { of a pandemic. To behave scientifically in this case, for example, is to stick to health } \\
\text { protocols by knowing its functions and benefits. }\end{array}$ \\
\hline$S 11$ & $\begin{array}{l}\text { The hot issue of Covid can be a bridge to understanding many essential materials such } \\
\text { as viruses, classifications, etc. And students can understand better about Covid and how } \\
\text { to prevent it in every day }\end{array}$ \\
\hline$S 16$ & Covid-19 related to diseases in the Natural Science material \\
\hline
\end{tabular}

\section{DISCUSSION}

The results of the dissemination of an open questionnaire survey that has been distributed to the bachelor of science education graduates, the result that science education graduates have a different meaning of SSI, but most of them have relatively the same knowledge as the opinion (S26) who has the view that: "SSI discusses social science issues ". This view is relevant to research, which holds that SSI is a representation of social problems related to science in the social aspect [6]. SSI represents an important social problem and is conceptually connected to science [4]. Development and social practice, investigation, and negotiation of SSI need integration with scientific concepts and processes [12]. SSI often involves science, technology, and unstructured problems related to social aspects [13].

Another relatively similar view of graduate science education graduates is to describe SSI as a problem related to controversial issues that are relevant to the view that SSI is a controversial integration that is socially relevant to science problems [14]. SSI in science education has a significant role in educating prospective citizens about many controversial issues 
that exist in everyday life. The controversial topic of SSI has an important scientific basis for society [15].

Another view is that SSI is a problem related to problems in the real life. This view is relevant to the opinion that SSI links a real-life problem that related to natural science [4] [5]. SSI supports students' learning about how students can negotiate by connecting science concepts with real-world issues. SSI is a science-based social challenge. SSI provides problems in the real world and in this situation students should have the opportunity to consider solutions to problems when they learn science in the classroom [5].

Another view of SSI, namely the view of S9, is relevant to the view that the SSI controversial issues arise and are related to current and current issues in society [16] which have a scientific basis and have an effect on the lives of individuals and communities [6]. View (S4) illustrates that SSI requires solutions from various aspects. This view is relevant to the view, that SSI is a problem in the real world that has many answers from various aspects such as culture, economics, and politics which include moral and ethical controversies [5]. SSI is a high-complexity conceptual problem with a wide range of contextual factors. Avoid simplifying the problem by focusing on one factor and leaving aside its broader contextual significance [4].

The view (S13) that SSI is a context in science learning. This view is relevant to the view that SSI is a context for learning about Science education [17], SSI aims to provide a rich context and support learners to explore important content of science [4]; because SSI helps students in understanding the relationship between science and the daily life of students [7]. SSI is a foundation pillar as the main context for learning science [17]. The interesting nature of the SSI context because it discusses scientific phenomena in the environment that can be a bridge of understanding for students [5].

The role of SSI from the survey that has been distributed is relatively the same, namely the role of SSI in scientific literacy, argumentation, decision making (S4), students' interest and enthusiasm for learning (S8), NOS (S27), critical thinking (S6), HOTS (S19) relevant with previous research which views that SSI plays a role in inquiry-based learning, comprehension of the nature of science [12], motivation and interest learners [7], production very important decisions [18], and impact on critical thinking skills [13]. SSI serves as a potent context to understanding NOS, scientific literacy, high-level thinking, scientific reasoning, and critical thinking, because SSI problems reasoning must implicate recognizing the problems attached in SSI's complexity, examined problems from several perspectives, appreciating SSI was subject to an ongoing investigation, and showed skepticism when providing the potential bias information [4]. SSI serving general culture, understanding technologyscience related society-environment, expanding scientific process skills, thinking, discussing, problem-solving skills, getting disposition/attitude, and having morals [6].

S2 has the view that SSI is an approach for the development of students' practices and attitudes/dispositions better whip up students for being active in social participation, especially in science context correlate with social problems [7]. The results of the questionnaire distribution show that there is a relationship between SSI and critical attitude. All samples argue that SSI can increase the critical attitude of students. This opinion is relevant to the view that SSI can influence critical thinking and critical attitude [13]. SSI decision-making affects critical thinking (CT), where CT be divided into dispositions and skills to result from reasonable decisions [19]. The common framework for analyzes sociological problems are based on eight topics that one of them summarized as a critical stance. The critical attitude inherent in a question can bring up important information [20].

SSI's relationship with a critical attitude, that SSI will encourage the curiosity of students in exploring information so that later it will form a critical attitude of students (S1), students can improve their critical attitude using SSI because students actively seek information from various aspects of knowledge (S3). Critical attitude has six sub-dimensions, one of which is curiosity. Curiosity is defined as the desire to know or intellectual curiosity [21]. The search for truth is the inclination of constant research to find the best explication for each claim. SSI has a role in science learning as well as for students. The role that "SSI helps students to analyze and evaluate issues, phenomena, and problems that students have to solve" (S9) is relevant to the role of SSI context-based learning as a method's science education is helping students improve their skills to analyze, evaluate, and infer large amounts of information [13].

SSI's relationship with a critical attitude in the process of finding solutions because, in problemsolving, students need critical thinking (S4), SSI requires students to be able to identify and evaluate the consequences of the problem or issue for the social life of the community and the surrounding environment, offering solutions that are appropriate in overcoming 
the issue, creating or designing activity steps in finding the best solution (S7). The role of SSI is used to develop solutions to problems that require thinking about causal relationships in the scientific phenomena that underlie the problem [7], it also serves as an important link that supports students in considering causal relationships from various forms of evidence, and coordinates various phenomena. from the scientific dimension [5].

Issues around SSI make students not misconceptions or can make students understand what happened because the integration of SSI into the instruction of science in schools allows students to have the occasion to build knowledge that makes sense of complex problems [17]. Insert SSI in science learning at classrooms inherently supply opportunities for learners to involve in beneficial discussions on modern science problems [4]. Students are able to discuss socio-scientific problems, argue, and communicate the results they get (S13). SSI-based discussions can involve students' critical thinking to generate reasons, make decisions, and assess what to believe or do [5], develop argumentative skills, and learn about relevant ethics [22]. Students need the opportunity to utilize their scientific knowledge to debate, discuss, and practice for decisions making about SSI problems [15].

The process of arguing will hone the scientific communication skills of students (S4). SSI shows a strong influence on the argumentation process, because SSI acts as a good context for testing students 'arguments [23], so that it can appear a role in improving the argumentation skills of students [15]. Argumentation is one of the constituents of scientific literacy [3]. The improvement of oral communication skills is also influenced by argumentation activities which also help to introduce knowledge into the real world [15].

The arguments will affect critical thinking aspects such as science incidents in social aspects, questioning information, and assumptions of individual and social positions in SSI problems [23]. Argumentation skills allow for making decisions and solving problems, especially complex problems such as SSI problems [24]. SSI can improve decision making in students so that it can improve skills directly [18]. Decisionmaking requires scientific communication about the use of science and technology [16] [25]. Problems in SSI be used as tool effective pedagogical to improve communication skills of students by increasing interaction between peers, stimulating students' reasoning, and building social knowledge from the context of science classrooms [9].
Covid 19 can be presented as SSI's problem in science learning in accordance with the views of science education graduates [26]. Students can be introduced in the context of Covid-19 to think about examining data, knowing the impact and role of politics during the Covid-19 pandemic, as well as the impact on other aspects. This activity will also help students to maintain cleanliness, using masks.

\section{CONCLUSION}

This research was utilized to see the views of several education graduates of science about SSI and the role of SSI in science learning, namely the influence of SSI on critical attitudes and scientific communication, as well as the use of SSI during the Covid-19 pandemic. The view of science education graduates that SSI is the context of controversial issues that comes from everyday life on scientific issues that are relevant to other aspects. The role of SSI can improve students' critical attitude because SSI problem solving requires students to analyze problems and deduce a lot of information. SSI also plays an important role in improving students' scientific communication. Science graduates are of the view that SSI can be applied during the Covid pandemic and some are of the view that the Covid-19 problem can be used as a context for problems in learning related to SSI.

\section{ACKNOWLEDGMENTS}

Researchers would like to thank the Yogyakarta State University graduate who has held an International Seminar on Science Education and the respondents so that this research can be carried out well.

\section{REFERENCES}

[1] T. Feierabend, I. Eilks, Raising Students' Perception of The Relevance of Science Teaching and Promoting Communication and Evaluation Capabilities Using Authentic and Controversial Socio-scientific Issues in The Framework of Climate Change, Science Education International 21 (2010) 176-196.

[2] ACDP. Rapid Review of Curriculum 2013 and Textbooks. Education Sector Analytical and Capacity Development Partnership (ACDP), 2017.

[3] M. Evagorou, Discussing a Socioscientific Issue in a Primary School Classroom: The Case of Using a Technology-Supported Environment in 
Formal and Nonformal Settings, in: T.D. Sadler (Eds.), Socio-scientific Issues in the Classroom, Springer, Dordrecht, Heidelberg, 2010, pp. 34-37 DOI: http://dx.doi.org/10.1007/978-94-007-1159-4_8

[4] T.D. Sadler, S.A. Barab, B. Scott, What Do Students Gain by Engaging in Socioscientific Inquiry?, Research in Science Education (2007) 371-391.

DOI: http://dx.doi.org/10.1007/s11165-006-9030-9

[5] L. Zangori, L. Ke, T .D. Sadler, A. Peel, Exploring Primary Students Causal Reasoning about Ecosystems, International Journal of Science Education 42 (2020) 1799-1817. DOI: http://dx.doi.org/10.1080/09500693.2020.17837 $\underline{18}$

[6] Ş.S. Anagün, M. Özden, Teacher candidate's perceptions regarding socio-scientific issues and their competencies in using socio-scientific issues in science and technology instruction, vol. 9, in: Procedia - Social and Behavioral Sciences, Elsevier Ltd., Amsterdam, 2010, pp. 981-985. DOI:

https://doi.org/10.1016/j.sbspro.2010.12.271

[7\} T.D. Sadler, Situated Learning in Science Education: Socio-scientific Issues As Contexts For Practice, Science Education 45 (2009) 1-42. DOI:

https://doi.org/10.1080/03057260802681839

[8] T.D. Sadler, Situating socio-scientific issues in classrooms as a means of achieving goals of science education, in the Classroom, Springer, Dordrecht, Heidelberg, vol. 39, 2011, pp. 1-9. DOI: https://doi.org/10.1007/978-94-007-1159$\underline{4} 1$

[9] Y. Chung, J. Yoo, S-W. Kim, H. Lee, D.L. Zeidler, Enhancing Students' Communication Skills in the Science Classroom Through Socioscientific Issues, International Journal of Science and Mathematics Education 14 (2014) 1-27. DOI: https://doi.org/10.1007/s10763-014-9557-6

[10].N.Y.T. Merchán, J.S. Contributions of intervention teaching using socioscientific issues to develop critical thinking, Ensenanza de las Ciencias 34 (2016) 43-65. DOI: http://dx.doi.org/10.5565/rev/ensciencias.1638

[11] A. Çinici, B. Ergin, The Effects of Discussion and Decision-Making Based Activities Concerning GMOs on Critical Thinking Dispositions of
Teacher Candidates, Necatibey Eğitim Fakültesi Elektronik Fen ve Matematik Eğitimi Dergisi 13 (2019) 735-758. DOI: http://dx.doi.org/10.17522/balikesirnef.531706

[12] P. Nuangchalerm, Engaging Students to Perceive Nature of Science Through Socioscientific Issues-based Instruction, European Journal of Social Sciences 13 (2010) 34-37.

[13].M.D. Gul, H. Akcay, Structuring A New Socioscientific Issues (SSI) Based Instruction Model: Impacts on Pre-Service Science Teachers' (PSST) Critical Thinking Skills And Dispositions, International Journal of Research in Education and Science 6 (2020) 141-159. DOI: https://doi.org/10.46328/ijres.v6i1.785

[14] T.D. Sadler, D.L. Zeidler, The significance of Content Knowledge for Informal Reasoning Regarding Socioscientific Issues: Applying Genetics Knowledge To Genetic Engineering Issues, Science Education 89 (2005) 71-93 DOI: https://doi.org/10.1002/sce.20023

[15].V. Dawson, K. Carson, Introducing Argumentation About Climate Change Socioscientific Issues in A Disadvantaged School, Research in Science Education (2018) 863-883. DOI: https://doi.org/10.1007/s11165018-9715-X

[16].N.D. Moreno, M.R. Jiménez-Liso, Las controversias sociocientíficas: temáticas e importancia para la educación científica, APACEureka, 9 (2012) 54-70. DOI: https://doi.org/10498/14624

[17] T.D. Sadler, V. Dawson, Socio-scientific issues in science education: contexts for the promotion of key learning outcomes, in: B. Fraser, K. Tobin, C.J. Robbie, Second International Handbook of Science Education, Springer, Dordrecht, Heidelberg, 2012, pp. 799-809. DOI: https://doi.org/10.1007/978-1-4020-9041-7_53

[18].M.A. Pike, Values and Visibility: The Implementation and Assessment of Citizenship Education in Schools, Educational Review, 13 (2007) 215-229. DOI: http://dx.doi.org/10.1080/00131910701255020

[19].R.H. Ennis, Critical Thinking Dispositions: Their Nature and Assessability, Informal Logic 18 (1996) 165-18. DOI: https://doi.org/10.22329/il.v18i2.2378 
[20] S.D. Kolstø, Scientific Literacy for Citizenship: Tools for Dealing with The Science Dimension of Controversial Socioscientific Issues, Science Education $85 \quad$ (2001) 291-310. DOI: https://doi.org/10.1002/sce.1011

[21] P.A. Facione, C.A. Sánchez, N.C. Facione, J. Gainen, The Disposition toward Critical Thinking, The Journal of General Education 44 (1995) $1-25$.

DOI: https://doi.org/10.22329/i1.v20i1.2254

[22] J. Lewis, J. Leach, Discussion of Socio-cientific Issues: The Role of Science Knowledge, International Journal of Science Education 44 (2006) 1267-1287. DOI: http://dx.doi.org/10.1080/09500690500439348

[23] O. Acar, L. Turkmen, A. Roychoudhury, Student Difficulties in Socio-scientific Argumentation and Decision-making Research Findings:
Crossing The Borders of Two Research Lines, International Journal of Science Education, 32 (2010) 1191-1206. DOI: http://dx.doi.org/10.1080/09500690902991805

[24] D.H. Jonassen, B. Kim, Arguing to Learn and Learning to Argue: Design Justifications and Guidelines, Educational Technology Research and Development 58 (2010) 439-457. DOI: http://dx.doi.org/10.1007/s11423-009-9143-8

[25] R. Levinson, Towards A Theoretical Framework For Teaching Controversial Socio-Scientific Issues, International Journal of Science Education 28 (2006) 1201-1224. DOI: http://dx.doi.org/10.1080/09500690600560753

[26] M.J. Reiss, Science Education in the Light of COVID-19, Science Education 44 (2020) 10791092. DOI: https://doi.org/10.1007/s11191-020$\underline{00143-5}$ 